\title{
Supplementation of sodium butyrate to postweaned heifer diets: Effects on growth performance, nutrient digestibility, and health
}

\author{
E. M. Rice, ${ }^{1 *}$ K. M. Aragona, ${ }^{1}$ S. C. Moreland, ${ }^{2}$ and P. S. Erickson ${ }^{1} \dagger$ \\ ${ }^{1}$ Department of Agriculture, Nutrition, and Food Systems, University of New Hampshire, Durham 03824 \\ ${ }^{2}$ Nutriad USA, Hampshire, IL 60140
}

\section{ABSTRACT}

The objective of this study was to determine the effect of varying levels of sodium butyrate (SB) supplementation in feed on the growth, digestibility, and health of postweaned heifers. Forty Holstein dairy heifers with a mean age of $84 \mathrm{~d}$ and average body weight (BW) of $100.9 \pm 11.2 \mathrm{~kg}$ were housed in a naturally ventilated freestall barn. Heifers were blocked by birth date and randomly assigned to 1 of 4 treatments in a completely randomized block design: (1) $100 \mathrm{~g}$ of soybean meal carrier (control), (2) $0.25 \mathrm{~g}$ of SB $/ \mathrm{kg}$ of BW plus carrier, (3) $0.50 \mathrm{~g}$ of $\mathrm{SB} / \mathrm{kg}$ of $\mathrm{BW}$ plus carrier, and (4) $0.75 \mathrm{~g}$ of $\mathrm{SB} / \mathrm{kg}$ of $\mathrm{BW}$ plus carrier. Carrier with or without SB was top-dressed and hand-mixed into a total mixed ration once daily. Heifers were fed to provide $10 \%$ orts. Initial BW, hip and withers heights, heart girth, and body length were measured before the start of the study and every week thereafter until the 14 -wk trial was over. Blood samples were obtained and plasma urea nitrogen, plasma glucose, and whole-blood $\beta$-hydroxybutyrate concentrations were determined before the start of treatment and weekly thereafter until the conclusion of the study. Fecal samples were taken before treatment and every other week from each heifer for coccidia counts. Apparent total-tract nutrient digestibility was determined using acid detergent insoluble ash as an internal marker. Each heifer underwent this phase from d 47 until d 54 of the study. Sodium butyrate had a positive effect on average BW and overall BW gain. Feed efficiency tended to improve as SB supplementation increased. Coccidia counts were lowest in the treatment with $0.25 \mathrm{~g}$ of $\mathrm{SB} / \mathrm{kg}$ of BW plus carrier. Sodium butyrate had no effects on skeletal growth or plasma urea nitrogen concentration.

Received August 9, 2018.

Accepted December 6, 2018.

*Present address: Department of Animal Science, University of Kentucky, Lexington 40506.

†Corresponding author: peter.erickson@unh.edu
Blood glucose concentration decreased linearly and $\beta$-hydroxybutyrate increased linearly with increasing levels of SB supplementation. Sodium butyrate supplementation did not affect apparent total-tract nutrient digestibility. Sodium butyrate supplementation offers positive results in the growth performance and feed efficiency of postweaned heifers.

Key words: sodium butyrate, postweaned heifer, growth, performance, coccidia

\section{INTRODUCTION}

The cost of raising replacement heifers constitutes almost 15 to $20 \%$ of all expenses on a dairy farm (Heinrichs, 1993). Establishing a well-developed, functional rumen in dairy calves is essential for improving growth performance and feed efficiency (FE), which can indirectly decrease costs of raising replacement heifers. Increased solid feed intake in calves stimulates the proliferation of microbial populations in the rumen, which in turn ferment carbohydrates (Bergman, 1990). The end products of this breakdown are rapidly converted into VFA in the rumen. The 3 main VFA produced are acetate, propionate, and butyrate. Butyrate is the most rapidly metabolized by rumen epithelium and plays a key role in establishing the rumen epithelium and subsequent rumen development (Beever, 1993).

Butyrate stimulates the growth of papillae that are embedded on the surface of the rumen epithelium (Tamate et al., 1962). These papillae, surrounded by blood vessels, are responsible for absorption in the rumen. Rumen papillae have a high affinity for absorption of VFA (Dobson et al., 1956). Butyrate stimulates papillae growth and elongation, which provides a greater surface area for nutrient absorption, supporting rumen development (Tamate et al., 1962).

Butyrate is critical in the development of the rumen and plays an important role in the establishment and maintenance of epithelium in the rumen and small intestine. Sodium butyrate (SB) is a commercially available butyrate product that positively affects growth rates, FE, and gut health. Calves intraruminally in- 
fused with SB had increased overall BW gain and more extensive papillae growth compared with calves infused with glucose or sodium acetate, propionate, or chloride (Sander et al., 1959). Supplementing SB in milk replacer (MR) of calves resulted in higher ADG and overall BW and BW gains compared feeding MR without SB (Guilloteau et al., 2009; Górka et al., 2011a). Calves supplemented with SB also had decreased incidence of scours and fewer days spent being treated (Górka et al., 2011a). A positive FE response and improved nutrient digestibility were seen in calves supplemented with SB in MR (Guilloteau et al., 2010).

In addition to improving calf performance, butyrate plays a role in the stimulation of epithelial growth. Calves supplemented with SB in MR had increased mitotic and decreased apoptotic indices in the small intestine compared with control calves (Guilloteau et al., 2009; Górka et al., 2011b, 2014). Supplementation of SB in starter grain increased rumen epithelium development (Górka et al., 2011a) and increased small intestinal development and villi height when SB was fed in MR (Guilloteau et al., 2009; Górka et al., 2011b, 2014). By increasing surface areas of the papillae and villi, butyrate enhances the absorptive capacity, resulting in improved epithelial maintenance, rumen development, and calf performance.

Butyrate's effect on epithelial cells and rumen development in calves is well known; however, its effects on postweaned heifers have yet to be investigated. Although the rumen at postweaning is near full development, the stimulatory effects of butyrate support further rumen development and suggest its possible involvement in the repair of damaged epithelium. The ability to replace damaged epithelial cells can help maintain an optimal rumen environment for the efficient breakdown and absorption of nutrients.

In other species, SB reduced the incidence of diarrhea and improved immune function and growth in weaning piglets (Piva et al., 2002; Fang et al., 2014). Supplementation of encapsulated butyrate also improved intestinal health and epithelial cell recovery after broilers were subjected to intestinal damage via heat stress or coccidiosis (Leeson et al., 2005; Abdelqader and AlFatafah, 2016). The stimulatory effects of butyrate on epithelial cell proliferation and repair support the possibility that its supplementation can improve rumen function and maintain epithelial integrity. Therefore, there is a benefit to investigating and determining the effects of SB on the performance, growth, and health of postweaned heifers. The objective of this study was to determine the effects of varying levels of SB on the growth performance, nutrient digestibility, and health of postweaned dairy heifers. We hypothesize that as SB levels increase, heifer growth performance and nutrient digestibility will increase.

\section{MATERIALS AND METHODS}

\section{Experimental Design and Treatments}

This experiment was reviewed and approved by the University of New Hampshire Animal Care and Use Committee (protocol no. 151002). Forty Holstein heifers with a mean age of $84 \mathrm{~d}$ and BW of $100.9 \pm 11.2$ $\mathrm{kg}$ (mean $\pm \mathrm{SD}$ ) were blocked by date of birth and randomly assigned to 1 of 4 treatments: (1) no SB (control), (2) $0.25 \mathrm{~g}$ of SB $/ \mathrm{kg}$ of BW (0.25SB), (3) $0.50 \mathrm{~g}$ of SB $/ \mathrm{kg}$ of BW (0.50SB), and (4) $0.75 \mathrm{~g}$ of $\mathrm{SB} / \mathrm{kg}$ of BW $(0.75 \mathrm{SB})$. Before the experiment, heifers were raised according to the standard operating procedures of the Fairchild Dairy Teaching and Research Center (University of New Hampshire). On d 1 of life, all calves received good-quality colostrum $(>50 \mathrm{~g}$ of $\mathrm{IgG} / \mathrm{L})$. Beginning on $\mathrm{d} 2$, calves received free-choice calf starter and water and $6 \mathrm{~L}$ of milk daily until weaning at $\mathrm{d} 56$, followed by a TMR until being placed in the study.

Dosage ranged from approximately 0.8 to $2.4 \%$ of DM based on heifers weighing $160 \mathrm{~kg}$ and consuming 5 $\mathrm{kg}$ of DM. These doses are within and above the recommendation of Górka et al. (2018), where 0.3 to $1.0 \%$ was supplemented to the concentrate portion of the diet. Dosages were used to determine optimum supplementation rate through orthogonal comparisons. Sample size was based on previous research conducted at our university that demonstrated that a randomized complete block design using 40 postweaned heifers is adequate to detect differences (Cabral et al., 2013). All heifers were given their respective treatments mixed with $100 \mathrm{~g}$ of a carrier (soybean meal) per day, and $0.25 \mathrm{SB}, 0.50 \mathrm{SB}$, and $0.75 \mathrm{SB}$ treatments were adjusted weekly according to individual BW. Heifers entered the study on the first Tuesday during wk 12 of life and remained on the study for approximately $14 \mathrm{wk}$. Heifers were individually fed a TMR to obtain 5 to $10 \%$ refusals, and treatments were top-dressed at $1030 \mathrm{~h}$ daily. Because SB is a fine, powdery substance, the researchers deemed that topdressing the treatment would ensure its adhesion to feed particles.

\section{Management and Feeding}

Heifers were group housed in a naturally ventilated freestall barn with mattresses bedded with kiln-dried sawdust. Two adjacent pens $(6.17 \times 4.88 \mathrm{~m}$ and 6.32 $\times 4.8 \mathrm{~m}$ ) were used, each having the capacity to hold 8 heifers. Heifers had ad libitum access to water through 
Table 1. Ingredient composition (\% of DM $\pm \mathrm{SD}$ ) of the experimental diet used February to August 2016

\begin{tabular}{lc}
\hline Item & Value \\
\hline Corn silage & $40.0 \pm 0.51$ \\
Hay crop silage & $27.5 \pm 4.50$ \\
Soy-urea mix & $10.9 \pm 0.71$ \\
Energy mix $^{2}$ & $17.3 \pm 4.57$ \\
Blood meal-rumen-protected Met mix & $3.3 \pm 0.03$ \\
Mineral-vitamin premix $^{4}$ & 2.0 \\
\hline
\end{tabular}

${ }^{1}$ Contained $69.14 \%$ soybean meal, $21.83 \%$ canola meal, $7.28 \%$ distillers grain, and $1.75 \%$ urea.

${ }^{2}$ Contained $45.80 \%$ corn meal, $34 \%$ beet pulp, $15.20 \%$ steam-flaked corn, and $5 \%$ molasses.

${ }^{3}$ Blood meal and rumen-protected Met at $3.9 \% \mathrm{CP}$.

${ }^{4}$ Contained $20 \% \mathrm{NaCl}, 19.05 \% \mathrm{Ca}, 6 \% \mathrm{P}, 3.51 \% \mathrm{Mg}, 2.01 \% \mathrm{~S}, 1.51 \%$ $\mathrm{K}, 0.26 \% \mathrm{Mn}, 0.26 \% \mathrm{Zn}, 0.29 \% \mathrm{Fe}, 602 \mathrm{mg} / \mathrm{kg} \mathrm{Cu}, 593.6 \mathrm{mg} / \mathrm{kg}$ organic $\mathrm{Cu}, 25.1 \mathrm{mg} / \mathrm{kg} \mathrm{Se}, 15 \mathrm{mg} / \mathrm{kg} \mathrm{I}, 15 \mathrm{mg} / \mathrm{kg} \mathrm{Co}, 267,800 \mathrm{IU} / \mathrm{kg}$ vitamin $\mathrm{A}, 111,071 \mathrm{IU} / \mathrm{kg}$ vitamin $\mathrm{D}_{3}$, and $2,207.3 \mathrm{IU} / \mathrm{kg}$ vitamin $\mathrm{E}$.

automatically refilling water troughs, and there was no competition for stall space. A 1-wk training period was allotted before application of treatment to train heifers to use Calan feeding doors (American Calan Inc., Northwood, NH).

Heifers were fed the formulated TMR (Tables 1 and 2) at $1030 \mathrm{~h}$ daily in individual feed tubs to allow for daily feed intake and refusal measurements. The feed was mixed and distributed using a motorized feeding vehicle (Data Ranger, American Calan Inc.). Before distributing fresh feed, refusals were removed from feed tubs and samples were obtained for analysis. The ration was fed to obtain 5 to $10 \%$ feed refusals, and the amount fed was adjusted daily according to individual intakes. Treatments were hand mixed into each heifer's feed.

\section{Feed Analysis}

The amount of feed offered and refused was measured daily at $1000 \mathrm{~h}$ to determine DMI. Samples of TMR and feed refusals from each heifer were obtained daily and frozen at $-20^{\circ} \mathrm{C}$ for future analysis. Frozen samples were thawed and placed in a forced hot-air convection oven (Binder, Bohemia, NY) to dry at $55^{\circ} \mathrm{C}$ for $48 \mathrm{~h}$ to determine DM. Ort samples were composited weekly by heifer, and TMR samples were composited monthly. All samples were ground through a 1-mm screen using a Wiley mill (Thomas Scientific, Swedesboro, NJ). All samples were sent to a commercial laboratory (Dairy One Forage Laboratory, Ithaca, NY) for nutrient analysis. Feed samples were analyzed for ADF (method 5 in an Ankom Fiber Analyzer A2000, Ankom Technology, Fairpoint, NY; method 973.18, AOAC International, 1998), NDF (method 6 in an Ankom Fiber Analyzer A2000 with $\alpha$-amylase and sodium sulfite, Ankom Tech- nology; solutions as in Van Soest et al., 1991), starch (YSI 2700 Select Biochemistry Analyzer, YSI Inc. Life Sciences, Yellow Springs, $\mathrm{OH}$ ), crude fat (ether extraction; method 2003.05, AOAC International, 2006), ash (method 942.05, AOAC International, 2006), and CP (method 990.03, AOAC International, 2006). Metabolizable energy intake was estimated by inputting the diet components into the NRC dairy program (NRC, 2001).

\section{Measurements and Blood Sampling and Analysis}

Heifers were weighed and skeletal measurements were taken before starting treatments and every Tuesday at $0830 \mathrm{~h}$ throughout the study. Heifers were measured for hip height, withers height, heart girth, and body length. Hip and withers heights were measured using a sliding-scale height stick with a bubble level. Hearth girth and body lengths were measured using a weight tape. To obtain weekly BW, heifers were weighed on a platform scale (Cardinal, Northeast Scale Co. Inc., Hooksett, NH).

Blood samples were obtained from the jugular vein using a 20-gauge needle before the administration of treatments. Once heifers were assigned to treatments, blood samples were collected every Tuesday at $0830 \mathrm{~h}$ for the duration of the study. Samples were collected in two 10-mL evacuated tubes, one containing anticoagulant (EDTA) and the other without anticoagulant (Monoject, Covidien, Mansfield, MA). Whole-blood concentrations of BHB were obtained using a handheld electronic blood glucose and ketone monitoring system (Nova Max Plus, Nova Biomedical, Waltham, MA; Deelen et al., 2016). Whole blood not containing EDTA was transferred to the sensor of the test strip using a disposable pipette. Samples with EDTA

Table 2. Ingredient composition (\% of DM $\pm \mathrm{SD}$ ) of the experimental diet used August 2016 to May 2017

\begin{tabular}{lc}
\hline Item & Value \\
\hline Corn silage & $40.9 \pm 0.26$ \\
Grass silage & $32.3 \pm 2.04$ \\
Soy-urea mix ${ }^{1}$ & $13.2 \pm 2.09$ \\
Energy mix $^{2}$ & $9.4 \pm 0.02$ \\
Blood meal and rumen-protected $\mathrm{Met}^{3}$ & $2.3 \pm 0.005$ \\
Mineral-vitamin premix & \\
\hline
\end{tabular}

${ }^{1}$ Contained $69.14 \%$ soybean meal, $21.83 \%$ canola meal, $7.28 \%$ distillers grain, and $1.75 \%$ urea.

${ }^{2}$ Contained $45.80 \%$ corn meal, $34 \%$ beet pulp, $15.20 \%$ steam-flaked corn, and $5 \%$ molasses.

${ }^{3}$ Blood meal and rumen-protected Met at $3.9 \% \mathrm{CP}$.

${ }^{4}$ Contained $20 \% \mathrm{NaCl}, 19.05 \% \mathrm{Ca}, 6 \% \mathrm{P}, 3.51 \% \mathrm{Mg}, 2.01 \% \mathrm{~S}, 1.51 \%$ $\mathrm{K}, 0.26 \% \mathrm{Mn}, 0.26 \% \mathrm{Zn}, 0.29 \% \mathrm{Fe}, 602 \mathrm{mg} / \mathrm{kg} \mathrm{Cu}, 593.6 \mathrm{mg} / \mathrm{kg}$ organic $\mathrm{Cu}, 25.1 \mathrm{mg} / \mathrm{kg} \mathrm{Se}, 15 \mathrm{mg} / \mathrm{kg} \mathrm{I}, 15 \mathrm{mg} / \mathrm{kg}$ Co, 267,800 IU $/ \mathrm{kg}$ vitamin $\mathrm{A}, 111,071 \mathrm{IU} / \mathrm{kg}$ vitamin $\mathrm{D}_{3}$, and $2,207.3 \mathrm{IU} / \mathrm{kg}$ vitamin $\mathrm{E}$. 
were placed on ice until they were centrifuged at 1,278 $\times g$ at $4^{\circ} \mathrm{C}$ for $20 \mathrm{~min}$ (5430R, Eppendorf, Hamburg, Germany). Plasma was stored in 2 aliquots at $-20^{\circ} \mathrm{C}$ until analysis of plasma urea nitrogen (PUN) and glucose. Urea concentrations were measured in duplicate using the diacetyl monoxime method and measured colorimetrically using a UV-visible spectrophotometer (Beckman Coulter Inc., Brea, CA) set at a wavelength of $540 \mathrm{~nm}$. Plasma glucose concentrations were determined in duplicate via Wako Autokit for Glucose (Wako Diagnostics, Mountain View, CA). Glucose measurements were read on a UV-visible spectrophotometer at a wavelength of $505 \mathrm{~nm}$.

\section{Digestibility Measurements}

An internal marker (acid detergent insoluble ash) was used as a digesta marker to estimate apparent total-tract nutrient digestibility. Feeds, orts, and feces were analyzed for ADF using the filter bag technique (method 5, Ankom Technology) followed by determination of acid insoluble ash according to Van Keulen and Young (1977). The equation used to estimate digestibility was

$$
\begin{gathered}
100-[100 \times(\% \text { ADIA in DM consumed } / \\
\% \text { ADIA in feces }) \times(\% \text { nutrient in feces } / \\
\% \text { nutrient in consumed DM })]
\end{gathered}
$$

where ADIA is acid detergent insoluble ash. Each of the 40 heifers underwent the digestibility phase at $\mathrm{d}$ 47 of study until d 54 of the study. Total mixed ration samples were taken d 2 through 5 , and individual refusal samples were collected d 3 through 6 . Refusals and TMR samples were then composited over the sampling days. Rectal fecal grab samples ( $140 \mathrm{~g} /$ sample) were collected via gloved hand by manually stimulating defecation or collecting directly from the rectum for the last $4 \mathrm{~d}$ every $12 \mathrm{~h}$ to represent a $24-\mathrm{h}$ period (d 4 : 1100 and $2300 \mathrm{~h}$; d 5: 0200 and $1400 \mathrm{~h}$; d 6: 0500 and $1700 \mathrm{~h} ; \mathrm{d}$ 7: 0800 and $2000 \mathrm{~h}$ ). Fresh samples over the 4-d period were combined to obtain a single composite and were frozen at $-20^{\circ} \mathrm{C}$. Fecal samples were thawed at room temperature and emptied into aluminum trays to be dried in a forced-air convection oven at $55^{\circ} \mathrm{C}$ for approximately $72 \mathrm{~h}$ until completely dried. The dried TMR, refusals, and fecal samples were ground through a 1-mm screen using a Wiley mill (Thomas Scientific). Ground samples were sent to Analab (Fulton, IL) for analysis. Fecal samples were analyzed for $\mathrm{CP}$, ADF, $\mathrm{NDF}$, fat, OM, and starch concentrations as previously described for feed samples.

\section{Coccidia Count}

Fecal samples were obtained from each heifer before the start of treatment and biweekly thereafter. Samples were analyzed for coccidian oocysts following the modified Wisconsin sugar fecal worm egg flotation method (Bliss and Kvasnicka, 1997). Heifers were observed daily for indications of illness and were treated accordingly. Two heifers from treatment 0.50SB were treated with penicillin for elevated body temperatures $\left(>39.17^{\circ} \mathrm{C}\right)$. One control heifer was treated with penicillin due to elevated body temperature. Treatment of coccidiosis followed a 5-d feeding program of $10 \mathrm{mg}$ of amprolium (1.25\%) crumbles (Corid, Huvepharma, Sofia, Bulgaria)/kg of BW per day. One heifer from treatment 0.50SB was treated following the suggested 5 -d feeding program. One control heifer was given amprolium at the suggested level for $10 \mathrm{~d}$ due to more severe symptoms of coccidiosis. Because the nutrient digestibility period was set on the dates of coccidiosis treatment, the digestibility period was moved to the following week for treated heifers.

\section{Statistical Analysis}

Initial BW, skeletal measurements, serum glucose, PUN, BHB, and coccidia counts served as covariates for their respective variables of interest. Weekly DMI, ADG, ME intake, FE (ADG/DMI), BW, skeletal measurements, and blood metabolites (whole-blood BHB, plasma glucose, and PUN) were analyzed as a randomized complete block design with repeated measures using the MIXED procedure of SAS 9.4 (SAS Institute Inc., Cary, NC) according to the following model:

$$
\mathrm{Y}_{\mathrm{ijkl}}=\mu+\mathrm{B}_{\mathrm{i}}+\mathrm{SB}_{\mathrm{j}}+\mathrm{W}_{\mathrm{k}}+\beta \mathrm{X}_{\mathrm{ij}}+\mathrm{SBW}_{\mathrm{jk}}+\mathrm{E}_{\mathrm{ijkl}} \text {, }
$$

where $Y_{i j k l}=$ the dependent variable; $\mu=$ the overall mean; $B_{i}=$ the random effect of block $\mathrm{i}(\mathrm{i}=1, \ldots, 10)$; $\mathrm{SB}_{\mathrm{j}}=$ the fixed effect of the jth SB amount $(\mathrm{j}=0,0.25$, 0.50 , or $0.75 \mathrm{~g} / \mathrm{kg}$ of $\mathrm{BW}) ; \mathrm{W}_{\mathrm{k}}=$ the fixed effect of the kth week of the study $(\mathrm{k}=1-14) ; \beta=$ the regression (covariate coefficient); $\mathrm{X}_{\mathrm{ij}}=$ the covariate measurement; $\mathrm{SBW}_{\mathrm{jk}}=$ the fixed interaction between the jth $\mathrm{SB}$ amount and the kth week; and $\mathrm{E}_{\mathrm{ijkl}}=$ the residual error, $\sim N\left(0, \sigma_{\mathrm{e}}^{2}\right)$. In this model, the random effect of heifer within block subclass was used as the error term for the effect of treatment. The residual errors are errors within heifer across time and represent errors from repeated measurements in the experimental units (heifers). All variables except average hip height, body length gain, and average coccidia count were modeled using a first-order autoregressive covariance spatial 
structure. First-order autoregressive resulted in the smallest Bayesian information criteria of the 4 covariate structures tested (compound symmetry, unstructured, Toeplitz, and first-order autoregressive). Average hip height was modeled using a Toeplitz covariance spatial structure because it resulted in the smallest Bayesian information criterion. Degrees of freedom were calculated using the Kenward-Roger approximation option of the MIXED procedure. Body length gain was modeled using compound symmetry covariance spatial structure because it resulted in the smallest Bayesian information criterion. Covariate $P$-values for BHB and body length were $>0.25$; therefore, they were removed from the model. Average coccidia count was modeled using an unstructured covariance spatial structure because it resulted in the smallest Bayesian information criterion. Single degree of freedom contrasts for linear, quadratic, and cubic effects were determined for all variables.

Final hip and withers heights, heart girth, and body length were analyzed as a randomized complete block design using the MIXED procedure of SAS 9.4 (SAS Institute Inc.) according to the following model:

$$
\mathrm{Y}_{\mathrm{ij}}=\mu+\mathrm{B}_{\mathrm{i}}+\mathrm{SB}_{\mathrm{j}}+\beta \mathrm{X}_{\mathrm{ij}}+\mathrm{E}_{\mathrm{ij}},
$$

where $\mathrm{Y}_{\mathrm{ij}}=$ the dependent variable; $\mu=$ the overall mean; $B_{i}=$ the random effect of block $i(i=1, \ldots, 10)$; $\mathrm{SB}_{\mathrm{j}}=$ the fixed effect of the jth SB amount $(\mathrm{j}=0,0.25$, 0.50 , or $0.75 \mathrm{~g} / \mathrm{kg}$ of $\mathrm{BW}$ ); $\beta=$ the regression (covariate coefficient); $\mathrm{X}_{\mathrm{ij}}=$ the covariate measurement; and $\mathrm{E}_{\mathrm{ij}}=$ the residual error, $\sim N\left(0, \sigma_{\mathrm{e}}^{2}\right)$. In this model, the random effect of heifer within block subclass was used as the error term for the effect of treatment when the firstorder autoregressive spatial structure was used. Degrees of freedom were calculated using the Kenward-Roger approximation option of the MIXED procedure. Single degree of freedom contrasts for linear, quadratic, and cubic effects were determined.

Apparent total-tract nutrient digestibility, initial measurements, and overall skeletal measurement gains were analyzed as a randomized complete block design using the MIXED procedure of SAS 9.4 (SAS Institute Inc.) according to the following model:

$$
\mathrm{Y}_{\mathrm{ij}}=\mu+\mathrm{B}_{\mathrm{i}}+\mathrm{SB}_{\mathrm{j}}+\mathrm{E}_{\mathrm{ij}},
$$

where $\mathrm{Y}_{\mathrm{ij}}=$ the dependent variable; $\mu=$ the overall mean; $B_{i}=$ the random effect of block $\mathrm{i}(\mathrm{i}=1, \ldots, 10)$; $\mathrm{SB}_{\mathrm{j}}=$ the fixed effect of the jth SB amount $(\mathrm{j}=0,0.25$, 0.50 , or $0.75 \mathrm{~g} / \mathrm{kg}$ of $\mathrm{BW})$; and $\mathrm{E}_{\mathrm{ij}}=$ the residual error, $\sim N\left(0, \sigma_{\mathrm{e}}^{2}\right)$. Degrees of freedom were calculated using the Kenward-Roger approximation option of the MIXED procedure. Single degree of freedom contrasts for linear, quadratic, and cubic effects were determined.

For all variables, significant treatment and interaction effects were noted at $P \leq 0.05$ and trends were noted at $0.05<P \leq 0.10$. Any data points with values greater or less than 2.5 SD away from the mean were considered outliers and removed from the data set. Eight glucose samples were removed from the data set due to being 2.5 SD above the mean, and 3 glucose samples were removed due to being $2.5 \mathrm{SD}$ below the mean.

\section{RESULTS}

The nutrient analysis of the TMR is presented in Table 3. Nutrient analysis of refusals by treatment is shown in Table 4. Nutrient analysis of refusals was similar to TMR nutrient analysis, indicating that little sorting occurred during the experiment. Dry matter intake, ME intake, FE, ADG, BW, and skeletal measurements are presented in Table 5.

Heifer average initial BW was $100.9 \pm 11.2 \mathrm{~kg}$ (mean $\pm \mathrm{SD}$ ) upon entering the study. Average BW increased $(P=0.04)$ and final BW tended $(P=0.07)$ to increase with increasing amounts of SB. Feed efficiency tended to increase as SB increased $(P=0.08)$. Average and final heart girth and body length were similar among treatments. There was a treatment $\times$ week interaction for heart girth and heart girth gain $(P<0.02)$. Overall BW gains increased linearly $(P=0.02)$ as SB treatment levels increased (Table 6). Overall gains for hip height, withers height, heart girth, and body length were all similar across treatments.

Fecal samples indicated the presence of coccidia, but counts were low and varied greatly among calves in each treatment (Table 7). There was a quadratic

Table 3. Nutrient analysis (\% of DM \pm SD, unless noted) of the experimental diet

\begin{tabular}{lc}
\hline Item & Value \\
\hline $\mathrm{CP}$ & $15.8 \pm 0.83$ \\
$\mathrm{ADF}$ & $25.8 \pm 2.63$ \\
$\mathrm{NDF}$ & $40.8 \pm 3.61$ \\
$\mathrm{Starch}$ & $21.6 \pm 3.65$ \\
$\mathrm{NFC}^{1}$ & $40.0 \pm 4.20$ \\
$\mathrm{Fat}$ & $3.9 \pm 0.68$ \\
$\mathrm{Ca}$ & $0.70 \pm 0.04$ \\
$\mathrm{P}$ & $0.56 \pm 0.03$ \\
$\mathrm{~K}$ & $1.64 \pm 0.16$ \\
$\mathrm{Mg}$ & $0.31 \pm 0.04$ \\
$\mathrm{Na}$ & $0.22 \pm 0.02$ \\
$\mathrm{~S}$ & $0.31 \pm 0.01$ \\
$\mathrm{ME},{ }^{2} \mathrm{Mcal}$ & 2.43 \\
\hline
\end{tabular}

${ }^{1} \mathrm{NFC}=100-[\mathrm{CP} \%+(\mathrm{NDF} \%-$ neutral detergent insoluble $\mathrm{CP}$ $\%)+$ fat $\%+\operatorname{ash} \%]$.

${ }^{2}$ Estimated from NRC (2001). 
Table 4. Nutrient analysis (\% of $\mathrm{DM} \pm \mathrm{SD}$ ) of refusals by treatment ${ }^{1}$

\begin{tabular}{lcccc}
\hline Item & Control & $0.25 \mathrm{SB}$ & $0.50 \mathrm{SB}$ & $0.75 \mathrm{SB}$ \\
\hline $\mathrm{CP}$ & $15.0 \pm 1.68$ & $14.9 \pm 1.54$ & $15.0 \pm 1.46$ & $15.2 \pm 1.20$ \\
$\mathrm{ADF}$ & $26.1 \pm 3.07$ & $26.8 \pm 2.47$ & $26.1 \pm 2.83$ & $25.9 \pm 2.70$ \\
$\mathrm{NDF}$ & $41.6 \pm 5.00$ & $42.5 \pm 3.60$ & $40.9 \pm 5.03$ & $40.6 \pm 3.63$ \\
Starch & $20.4 \pm 4.21$ & $19.6 \pm 2.90$ & $20.9 \pm 4.26$ & $20.6 \pm 3.32$ \\
NFC & $32.3 \pm 5.3$ & $31.4 \pm 3.05$ & $32.5 \pm 5.65$ & $32.3 \pm 3.47$ \\
Fat & $4.0 \pm 0.47$ & $3.80 \pm 0.36$ & $3.79 \pm 0.85$ & $3.60 \pm 0.414$ \\
Ash & $7.22 \pm 0.47$ & $7.38 \pm 0.46$ & $7.82 \pm 0.87$ & $8.23 \pm 0.98$ \\
\hline
\end{tabular}

${ }^{1}$ Control $=$ no sodium butyrate $0.25 \mathrm{SB}=0.25 \mathrm{~g}$ of sodium butyrate $/ \mathrm{kg}$ of $\mathrm{BW} ; 0.50 \mathrm{SB}=0.50 \mathrm{~g}$ of sodium butyrate $/ \mathrm{kg}$ of $\mathrm{BW} ; 0.75 \mathrm{SB}=0.75 \mathrm{~g}$ of sodium butyrate $/ \mathrm{kg}$ of $\mathrm{BW}$.

effect $(P=0.03)$ that indicated that the $0.25 \mathrm{SB}$ treatment was most effective in reducing the prevalence of coccidia. Heifers in the final blocks of the study had numerically higher coccidia counts with a significant block effect $(P=0.0001)$.

Plasma concentrations of glucose and PUN and whole-blood BHB are presented in Table 7. Eight plasma glucose samples were removed from the data set due to being 2.5 SD above the mean, and 3 glucose samples were removed due to being $2.5 \mathrm{SD}$ below the mean. Glucose concentrations decreased $(P=0.003)$ as SB increased. Plasma urea nitrogen concentrations were similar among treatments. Average BHB concentrations increased linearly $(P=0.009)$ over the study as SB levels increased. Final BHB concentrations also increased linearly $(P=0.014)$ as SB levels increased.

Data collected during the digestibility measurement period are shown in Table 8 . There were no digestibility differences due to SB supplementation on any of the nutrients measured.

\section{DISCUSSION}

In the present study, butyrate was fed at $0.25,0.50$, or $0.75 \mathrm{~g}$ of $\mathrm{SB} / \mathrm{kg}$ of BW. Sodium butyrate was chosen as the dietary source of butyrate because it dissolves quickly in liquids and has been used in previous ruminant research. In many of these studies, SB was

Table 5. Intake and growth performance of heifers fed sodium butyrate from 12 to 26 wk of age

\begin{tabular}{|c|c|c|c|c|c|c|c|c|c|}
\hline \multirow[b]{2}{*}{ Item } & \multicolumn{4}{|c|}{ Treatment $^{1}$} & \multirow[b]{2}{*}{$\mathrm{SEM}^{2}$} & \multicolumn{4}{|c|}{$P$-value ${ }^{3}$} \\
\hline & Control & $0.25 \mathrm{SB}$ & $0.50 \mathrm{SB}$ & $0.75 \mathrm{SB}$ & & $\mathrm{L}^{4}$ & $\mathrm{Q}^{5}$ & $\mathrm{C}^{6}$ & $\operatorname{Trt} \times \mathrm{wk}^{7}$ \\
\hline Initial BW, kg & 96.9 & 97.5 & 108.7 & 100.5 & 3.56 & 0.17 & 0.23 & 0.30 & \\
\hline Average BW, kg & 157.5 & 159.0 & 160.4 & 164.4 & 2.37 & 0.04 & 0.58 & 0.23 & 0.68 \\
\hline $\mathrm{ADG}, \mathrm{kg} / \mathrm{d}$ & 1.16 & 1.15 & 1.17 & 1.24 & 0.04 & 0.12 & 0.32 & 0.36 & 0.37 \\
\hline Final BW, kg & 214.2 & 213.8 & 215.5 & 222.5 & 3.36 & 0.07 & 0.26 & 0.30 & \\
\hline DMI, $\mathrm{kg} / \mathrm{d}$ & 5.09 & 4.84 & 5.19 & 4.91 & 0.24 & 0.85 & 0.93 & 0.25 & 0.99 \\
\hline Mcal intake per day & 12.3 & 11.7 & 12.6 & 11.9 & 0.57 & 0.89 & 0.89 & 0.26 & 0.99 \\
\hline Feed efficiency, ADG/DMI & 0.24 & 0.26 & 0.23 & 0.28 & 0.01 & 0.08 & 0.12 & 0.01 & 0.07 \\
\hline Hip height, cm & 109.0 & 109.7 & 109. 0 & 109.5 & 0.53 & 0.81 & 0.80 & 0.33 & 0.71 \\
\hline Hip height gain, $\mathrm{cm} / \mathrm{d}$ & 0.19 & 0.21 & 0.19 & 0.20 & 0.01 & 1.00 & 0.64 & 0.22 & 0.46 \\
\hline Hip height final, cm & 117.6 & 119.2 & 117.8 & 118.4 & 0.62 & 0.76 & 0.38 & 0.08 & \\
\hline Withers height, cm & 105.6 & 105.4 & 106.0 & 104.7 & 0.39 & 0.29 & 0.13 & 0.06 & 0.60 \\
\hline Withers height gain, cm/d & 0.20 & 0.20 & 0.20 & 0.19 & 0.01 & 0.71 & 0.59 & 0.45 & 0.28 \\
\hline Withers height final, cm & 114.2 & 114.0 & 114.7 & 113.7 & 0.55 & 0.74 & 0.39 & 0.25 & \\
\hline Heart girth, cm & 124.5 & 124.4 & 124.7 & 125.6 & 0.74 & 0.28 & 0.47 & 0.53 & 0.01 \\
\hline Heart girth gain, $\mathrm{cm} / \mathrm{d}$ & 0.28 & 0.28 & 0.29 & 0.30 & 0.01 & 0.39 & 0.68 & 0.73 & 0.0031 \\
\hline Heart girth final, $\mathrm{cm}$ & 137.4 & 137.3 & 138.1 & 139.0 & 0.98 & 0.20 & 0.61 & 0.65 & \\
\hline Body length, cm & 107.9 & 107.6 & 107.9 & 107.2 & 0.67 & 0.58 & 0.73 & 0.46 & 0.68 \\
\hline Body length gain, $\mathrm{cm} / \mathrm{d}$ & 0.27 & 0.28 & 0.27 & 0.27 & 0.01 & 0.66 & 1.00 & 0.78 & 0.57 \\
\hline Body length final, cm & 120.2 & 120.3 & 119.6 & 119.8 & 1.02 & 0.75 & 0.96 & 0.81 & \\
\hline
\end{tabular}

${ }^{1}$ Control $=$ no sodium butyrate $0.25 \mathrm{SB}=0.25 \mathrm{~g}$ of sodium butyrate $/ \mathrm{kg}$ of $\mathrm{BW} ; 0.50 \mathrm{SB}=0.50 \mathrm{~g}$ of sodium butyrate $/ \mathrm{kg}$ of $\mathrm{BW} ; 0.75 \mathrm{SB}=0.75$ $\mathrm{g}$ of sodium butyrate $/ \mathrm{kg}$ of BW.

${ }^{2} \mathrm{SEM}=$ standard error of treatment.

${ }^{3} P$-value significant if $\leq 0.05$, trend if $\leq 0.10$.

${ }^{4} \mathrm{~L}=$ linear contrast.

${ }^{5} \mathrm{Q}=$ quadratic contrast.

${ }^{6} \mathrm{C}=$ cubic contrast.

${ }^{7}$ Trt $\times$ wk $=$ treatment by week interaction. 
Table 6. Overall BW and skeletal measurement gains of heifers fed sodium butyrate from 12 to 26 wk of age

\begin{tabular}{lrrrrrrrrr}
\hline & \multicolumn{4}{c}{ Treatment $^{1}$} & & \multicolumn{3}{c}{$P$-value $^{3}$} \\
\cline { 2 - 4 } Item & Control & $0.25 \mathrm{SB}$ & $0.50 \mathrm{SB}$ & $0.75 \mathrm{SB}$ & SEM $^{2}$ & Linear & Quadratic & Cubic \\
\hline BW, kg & 111.5 & 111.4 & 118.1 & 121.5 & 3.43 & 0.02 & 0.62 & 0.63 \\
Hip, cm & 18.8 & 20.4 & 18.7 & 19.4 & & 0.55 & 0.99 & 0.44 & 0.05 \\
Withers, cm & 19.4 & 19.2 & 19.9 & 18.7 & 0.52 & 0.54 & 0.37 & 0.21 \\
Heart girth, cm & 28.3 & 28.1 & 28.0 & 29.3 & 0.92 & 0.50 & 0.41 & 0.59 \\
Body length, cm & 26.9 & 27.2 & 26.4 & 26.6 & 0.91 & & 0.66 & 1.00 & 0.78 \\
\hline
\end{tabular}

${ }^{1}$ Control $=$ no sodium butyrate; $0.25 \mathrm{SB}=0.25 \mathrm{~g}$ of sodium butyrate $/ \mathrm{kg}$ of $\mathrm{BW} ; 0.50 \mathrm{SB}=0.50 \mathrm{~g}$ of sodium butyrate $/ \mathrm{kg}$ of $\mathrm{BW} ; 0.75 \mathrm{SB}=0.75 \mathrm{~g}$ of sodium butyrate $/ \mathrm{kg}$ of $\mathrm{BW}$.

${ }^{2} \mathrm{SEM}=$ standard error of treatment.

${ }^{3} P$-value significant if $\leq 0.05$, trend if $\leq 0.10$.

supplemented into MR fed to calves and main effects on calf performance were assessed. Because milk or MR bypass the rumen and empty directly into the abomasum of calves, SB in MR has the largest effects on the abomasum and small intestine (Guilloteau et al., 2009; Górka et al., 2011a). In this study, we were interested in evaluating the effects of SB supplementation on postweaned heifers; therefore, SB was mixed into the solid feed of each heifer. Because of the high solubility of SB, when it reaches the reticulorumen it rapidly dissociates and is almost completely absorbed by the rumen epithelium (Britton and Krehbiel, 1993). After conducting an in situ degradability pilot study, we were able to determine that SB contained $90 \pm 5 \%$ butyrate and was 99\% degradable in the rumen (E. M. Rice, unpublished data). After $4 \mathrm{~h}$ of incubation in the rumen, there was $98 \%$ disappearance of $\mathrm{SB}$. We were able to ensure that SB was consumed by determining whole-blood BHB concentration of each heifer weekly.

Our results are consistent with findings from previous studies where calves supplemented with SB in MR had improved FE and BW gains compared with calves not fed SB. Guilloteau et al. (2009) found that SB increased the length of the duodenum and villi, which improves the absorptive capacity of the small intestine. Similarly, we found that DMI and ME intake did not differ across treatments. However, overall BW increased linearly and final BW tended to increase linearly as SB levels increased. These responses may be direct effects of increased intestinal villi length or improved maintenance of the rumen epithelium, allowing the heifers to absorb more nutrients. There was a linear trend $(P$ $=0.08$ ) for increased FE as SB levels increased. Feed efficiency was increased by $16.67 \%$ in heifers fed $0.75 \mathrm{SB}$

Table 7. Coccidia count, plasma glucose and urea nitrogen, and whole-blood BHB concentrations of heifers fed sodium butyrate from 12 to 26 wk of age

\begin{tabular}{|c|c|c|c|c|c|c|c|c|}
\hline \multirow[b]{2}{*}{ Item } & \multicolumn{4}{|c|}{ Treatment $^{1}$} & \multirow[b]{2}{*}{$\mathrm{SEM}^{2}$} & \multicolumn{3}{|c|}{$P$-value ${ }^{3}$} \\
\hline & Control & $0.25 \mathrm{SB}$ & $0.50 \mathrm{SB}$ & $0.75 \mathrm{SB}$ & & $\mathrm{L}^{4}$ & $\mathrm{Q}^{5}$ & $\mathrm{C}^{6}$ \\
\hline Coccidia, count $/ 150 \mathrm{~g}$ of feces & 573.5 & 359.0 & 412.0 & 537.0 & 76.6 & 0.87 & 0.03 & 0.56 \\
\hline Initial glucose, mg/dL & 70.5 & 84.2 & 73.8 & 79.6 & 8.8 & 0.65 & 0.63 & 0.25 \\
\hline Glucose, $\mathrm{mg} / \mathrm{dL}$ & 90.5 & 85.7 & 87.19 & 79.97 & 2.3 & 0.003 & 0.60 & 0.01 \\
\hline Final glucose, mg/dL & 106 & 87.9 & 75.1 & 91.7 & 11.7 & 0.29 & 0.13 & 0.95 \\
\hline Initial PUN, ${ }^{7} \mathrm{mg} / \mathrm{dL}$ & 28.2 & 27.8 & 27.0 & 27.8 & 2.6 & 0.86 & 0.82 & 0.95 \\
\hline PUN, mg/dL & 31.8 & 32.8 & 30.4 & 30.8 & 1.3 & 0.33 & 0.83 & 0.60 \\
\hline Final PUN, mg/dL & 31.4 & 31.9 & 30.7 & 30.6 & 1.6 & 0.61 & 0.85 & 0.90 \\
\hline Initial $\mathrm{BHB},{ }^{8} \mathrm{mmol} / \mathrm{L}$ & 0.46 & 0.59 & 0.47 & 0.58 & 0.05 & 0.25 & 0.79 & 0.02 \\
\hline $\mathrm{BHB}, \mathrm{mmol} / \mathrm{L}$ & 0.54 & 0.57 & 0.60 & 0.61 & 0.02 & 0.009 & 0.59 & 0.51 \\
\hline Final BHB, mmol/L & 0.41 & 0.60 & 0.57 & 0.69 & 0.07 & 0.01 & 0.64 & 0.03 \\
\hline
\end{tabular}

${ }^{1}$ Control $=$ no sodium butyrate; $0.25 \mathrm{SB}=0.25 \mathrm{~g}$ of sodium butyrate $/ \mathrm{kg}$ of $\mathrm{BW} ; 0.50 \mathrm{SB}=0.50 \mathrm{~g}$ of sodium butyrate $/ \mathrm{kg}$ of $\mathrm{BW} ; 0.75 \mathrm{SB}=0.75 \mathrm{~g}$ of sodium butyrate $/ \mathrm{kg}$ of $\mathrm{BW}$.

${ }^{2} \mathrm{SEM}=$ standard error of treatment.

${ }^{3} P$-value significant if $\leq 0.05$, trend if $\leq 0.10$.

${ }^{4} \mathrm{~L}=$ linear contrast.

${ }^{5} \mathrm{Q}=$ quadratic contrast.

${ }^{6} \mathrm{C}=$ cubic contrast.

${ }^{7} \mathrm{PUN}=$ plasma urea nitrogen.

${ }^{8} \mathrm{BHB}=$ plasma BHB. 
Table 8. Apparent total-tract nutrient digestibility (\%)

\begin{tabular}{|c|c|c|c|c|c|c|c|c|}
\hline \multirow[b]{2}{*}{ Item } & \multicolumn{4}{|c|}{ Treatment $^{1}$} & \multirow[b]{2}{*}{$\mathrm{SEM}^{2}$} & \multicolumn{3}{|c|}{$P$-value ${ }^{3}$} \\
\hline & Control & $0.25 \mathrm{SB}$ & $0.50 \mathrm{SB}$ & $0.75 \mathrm{SB}$ & & $\mathrm{L}^{4}$ & $\mathrm{Q}^{5}$ & $\mathrm{C}^{6}$ \\
\hline DM & 76.2 & 73.3 & 70.5 & 68.1 & 9.2 & 0.43 & 0.96 & 0.71 \\
\hline $\mathrm{CP}$ & 71.6 & 65.5 & 66.4 & 56.0 & 14.1 & 0.38 & 0.83 & 0.45 \\
\hline $\mathrm{ADF}$ & 49.3 & 53.4 & 41.3 & 51.7 & 13.7 & 0.92 & 0.75 & 0.49 \\
\hline NDF & 61.8 & 59.5 & 51.8 & 58.3 & 11.3 & 0.66 & 0.59 & 0.81 \\
\hline Hcell $^{7}$ & 67.5 & 68.1 & 59.5 & 72.3 & 5.0 & 0.76 & 0.15 & 0.11 \\
\hline Starch & 98.83 & 98.14 & 98.52 & 98.63 & 0.30 & 0.86 & 0.19 & 0.33 \\
\hline $\mathrm{OM}$ & 77.4 & 74.8 & 72.2 & 69.8 & 8.7 & 0.43 & 0.48 & 0.71 \\
\hline Fat & 85.6 & 83.6 & 81.3 & 82.4 & 7.9 & 0.72 & 0.75 & 0.97 \\
\hline Ash & 59.3 & 48.5 & 48.1 & 44.2 & 10.7 & 0.43 & 0.77 & 0.52 \\
\hline $\begin{array}{l}{ }^{1} \text { Contro } \\
\text { butyrat } \\
{ }^{2} \mathrm{SEM}= \\
{ }^{3} \mathrm{P} \text {-valu } \\
{ }^{4} \mathrm{~L}=\text { lir } \\
{ }^{5} \mathrm{Q}=\mathrm{q} \\
{ }^{6} \mathrm{C}=\mathrm{cl} \\
{ }^{7} \mathrm{HCell}\end{array}$ & $\begin{array}{l}\text { sodium } \\
\text { f BW; } 0.7 \\
\text { lard error } \\
\text { ficant if } \leq \\
\text { ntrast. } \\
\text { ic contrast } \\
\text { ntrast. } \\
- \text { ADF. }\end{array}$ & $\begin{array}{l}\text { ate; } 0.25 \\
=0.75 \mathrm{~g} \\
\text { eatment. } \\
\text { trend if }\end{array}$ & $\begin{array}{l}=0.25 \mathrm{~g} \\
\text { odium bi }\end{array}$ & $\begin{array}{l}\text { odium br } \\
\text { ate } / \mathrm{kg} \text { of }\end{array}$ & te $/ \mathrm{kg} \mathrm{o}$ & $\mathrm{V} ; 0.5 \mathrm{C}$ & $=0.50$ & sodil \\
\hline
\end{tabular}

compared with heifers fed no SB. We also observed that SB levels increased as final BW increased, which relates to improved growth performance and FE.

Overall, there was a positive linear response of increased SB amounts to greater average BW and overall BW gains. We observed that heifers fed the highest level of SB had $4.4 \%$ greater average BW and $3.9 \%$ greater final BW compared with heifers fed no SB. Górka et al. (2011a) observed that calves that were supplemented with $\mathrm{SB}$ in $\mathrm{MR}$ had greater $\mathrm{ADG}(P<$ $0.09)$ and greater BW $(P<0.10)$ during the first weeks of treatment compared with calves without SB supplementation. They also observed that reticulorumen weight and papillae length and width were greatest in calves fed SB. This correlates with an enhanced absorptive capacity in the rumen due to improved papillae morphology and surface area.

Supplementing SB in the present study did not have an effect on hip height, withers height, heart girth, and body length measurements. In a study by Ferreira and Bittar (2011), sodium monensin, SB, and sodium propionate were supplemented in the starter grain of calves during pre- and postweaning periods. In that study, all animals had similar growth performance and there were no differences in withers height, heart girth, or hip width. Calves supplemented with SB had decreased starter intake during one period of the study, but skeletal and BW gains remained similar across all treatments. This suggests improved FE in SB calves because even though calves had lower intakes they continued to grow at the same rates as calves fed sodium monensin or sodium propionate. Although no significant growth differences were detected, these results suggest that SB may be used as a replacement for sodium monensin because it resulted in equal performance.

In the current study, there was a quadratic effect $(P$ $=0.03)$ of $\mathrm{SB}$ on reducing the prevalence of coccidian oocysts in the feces. Sodium butyrate fed at $0.25 \mathrm{~g} /$ $\mathrm{kg}$ of BW was the most effective in reducing coccidian oocyst count. Górka et al. (2011a) observed that calves supplemented with encapsulated SB in starter grain had fewer days experiencing scours than calves without SB $(P=0.03)$. Calves with $\mathrm{SB}$ in starter also tended to have fewer days being treated with electrolytes $(P$ $=0.09$ ) compared with calves with no SB. A second study by Górka et al. (2011b) determined that calves fed SB in MR had increased mitotic indices $(P=0.01)$ compared with calves fed MR without SB (4.8 vs. $3.0 \%$, respectively). Apoptotic indices decreased $4 \%$ in calves fed MR with SB $(P<0.01)$ compared with $7.4 \%$ in calves fed no SB. Elevated mitotic indices of the intestinal epithelial cells indicate an increased rate of cell division. This elevated cell growth and decreased apoptosis improve the capability of the intestines to repair the damage inflicted by scours. There was a block effect $(P=0.0001)$ in which heifers in the final blocks had greater coccidia counts compared with heifers in earlier blocks. As the study progressed, the number of heifers that had been housed in the pens increased, which may have led to higher concentrations of oocysts in the environment. Therefore, heifers in the final blocks that were exposed to this may have been at a greater risk of coccidiosis. Also, the final blocks were conducted in the spring, where temperature extremes are common in the northeastern United States, which may contribute to the higher coccidia oocyst counts. 
The effects of SB supplementation have also been evaluated in other species. In broiler chickens, supplementation of SB $(0,500,1,000$, and $2,000 \mathrm{mg} / \mathrm{kg}$ of DM) resulted in a linear reduction in Lactobacillus count and an increase in jejunal villus height:crypt depth ratio as SB increased (Hu and Guo, 2007). These researchers also observed greater BW as SB level increased, suggesting that SB improved performance and intestinal morphology. Similarly, supplementing piglets with SB in MR $(0.3 \mathrm{~g} / 100 \mathrm{~g}$ of $\mathrm{DM})$ resulted in greater crypt depth, villi length, and mucosal thickness in the ileum as well as increased ADG and final BW (Kotunia et al., 2004).

In this study, there was no effect of SB on PUN concentrations in heifers, as also observed by Krehbiel et al. (1992). Increasing levels of ruminal butyrate in Holstein steers did not affect concentrations of PUN. As expected, in this study, whole-blood BHB levels increased with increasing SB levels. Increasing ruminal butyrate from SB supplementation increased ketogenesis, as reflected by the linear increase in BHB; this agrees with other studies in which supplemental butyrate was provided (Huhtanen et al., 1993; Herrick et al., 2018). Supplemental SB resulted in a linear decrease in plasma glucose $(P=0.003)$, which supports other research showing a reduction in plasma glucose when butyrate or SB was infused into lactating cows (Huhtanen et al., 1993; Herrick et al., 2018) This may be due to the heifers relying more heavily on gluconeogenesis as more ruminal development occurred. However, the lesser blood glucose concentration could be caused by a reduction in propionate uptake by the hepatocyte (Aiello et al., 1989) or butyrate inhibiting the conversion of propionate to glucose as observed in vitro (Demigné et al., 1986; Chow et al., 1990).

Due to digestive adaptations that occur as the calf transitions from a preruminant to a ruminant, there is a shift from absorption of glucose in the intestine to gluconeogenesis in the liver (Baldwin et al., 2004). Baldwin et al. (2004) reviewed research evaluating hepatic enzyme activity and found that glycolytic enzyme activity was increased in preruminants and decreased in ruminants. In the present study, plasma glucose concentration decreased as SB increased, suggesting that SB may have stimulated this enzymatic activity. However, final glucose concentrations in the present experiment were variable. Moreover, ruminants have greater hepatic enzyme activity related to gluconeogenesis than preruminants. As the animal matures and fermentation becomes more important, less carbohydrate will be available for digestion postruminally, resulting in less absorption of glucose.

The results from this study indicate that SB supplementation in feed can improve BW gain and increase
FE. Dry matter intakes were not different for treatments, but there was a trend for increased $\mathrm{FE}$ as $\mathrm{SB}$ levels were fed in higher amounts. As SB levels increased, ADG, average BW, and final BW of heifers also increased. Butyrate is the main VFA utilized by the rumen to increase growth and concentration of rumen papillae. Increasing the available surface area for nutrient absorption will allow the heifer to more effectively absorb and utilize nutrients obtained from fermentation. These nutrients can effectively optimize BW and skeletal growth gains. Improving growth performance can ensure that heifers reach breeding age younger and enter the milking herd sooner. Therefore, more research should be conducted to investigate the usefulness of SB in improving $\mathrm{FE}$ and growth performance and decreasing the prevalence of scours and coccidiosis outbreaks.

\section{ACKNOWLEDGMENTS}

We thank Nutriad for their financial support and the sodium butyrate used in this experiment, the Fairchild Dairy Teaching and Research Center staff for their help with the study, Jaqueline Jamieson (University of New Hampshire) for coccidia counting, and Meaghan Clark (University of New Hampshire. for conducting the plasma glucose assay. Partial funding was provided by the New Hampshire Agricultural Experiment Station. This is scientific contribution number 2789. This work was supported by the USDA National Institute of Food and Agriculture Project (Hatch Multistate NC2042; accession number 1001283).

\section{REFERENCES}

Abdelqader, A., and A. Al-Fatafah. 2016. Effect of dietary butyric acid on performance, intestinal morphology, microflora composition and intestinal recovery of heat-stressed broilers. Livest. Sci. 183:78-83.

Aiello, R. J., L. E. Armentano, S. J. Bertics, and A. T. Murphy. 1989. Volatile fatty acid uptake and propionate metabolism in ruminant hepatocytes. J. Dairy Sci. 72:942-949. https://doi.org/10.3168/jds .S0022-0302(89)79187-6.

AOAC International. 1998. Official Methods of Analysis. 16th ed. AOAC International, Arlington, VA.

AOAC International. 2006. Official Methods of Analyses. 18th ed. AOAC International, Gaithersburg, MD.

Baldwin, R. L. VI, K. R. McLeod, J. L. Klotz, and R. N. Heitmann. 2004. Rumen development, intestinal growth, and hepatic metabolism in the pre- and postweaning ruminant. J. Dairy Sci. 87(Suppl.):E55-E65. https://doi.org/10.3168/jds.S0022 -0302(04)70061-2.

Beever, D. E. 1993. Rumen function. Pages 186-215 in Quantitative Aspects of Ruminant Digestion and Metabolism. J. M. Forbes and J. France, ed. CAB International, Wallingford, UK.

Bergman, E. N. 1990. Energy contributions of volatile fatty acids from the gastrointestinal tract in various species. Physiol. Rev. 70:567-590.

Bliss, D. H., and W. G. Kvasnicka. 1997. The fecal examination: A missing link in food animal practice. Compend. Contin. Educ. Pract. Vet. 19:S104-S109.

Journal of Dairy Science Vol. 102 No. 4, 2019 
Britton, R., and C. Krehbiel. 1993. Nutrient metabolism in gut tissue. J. Dairy Sci. 76:2125-2131.

Cabral, R. G., P. S. Erickson, N. E. Guindon, E. J. Kent, C. E. Chapman, K. M. Aragona, M. D. Cabral, E. C. Massa, N. T. Antaya, C. C. Muir, B. O'Donnell, and M. E. Branine. 2013. Effects of lasalocid and intermittent feeding of chlortetracycline on the growth of prepubertal dairy heifers. J. Dairy Sci. 96:4578-4585.

Chow, J. C., C. Planck-Meyer, and B. W. Jesse. 1990. Gluconeogenic dependence on ketogenesis in isolated sheep hepatocytes. J. Dairy Sci. 73:683-689.

Deelen, S. M., K. E. Leslie, M. A. Steele, E. Eckert, H. E. Brown, and T. J. DeVries. 2016. Validation of a calf-side $\beta$-hydroxybutyrate test and its utility for estimation of starter intake in dairy calves around weaning. J. Dairy Sci. 99:7624-7633.

Demigné, C., C. Yacoub, C. Rémésy, and P. Fafournoux. 1986. Propionate and butyrate metabolism in rat or sheep hepatocytes. Biochim. Biophys. Acta 875:535-542.

Dobson, M. J., W. C. B. Brown, A. Dobson, and A. T. Phillipson 1956. A histological study of the organization of the rumen epithelium of sheep. Q. J. Exp. Physiol. Cogn. Med. Sci. 41:247-253.

Fang, C. L., H. Sun, J. Wu, H. H. Niu, and J. Feng. 2014. Effects of sodium butyrate on growth performance, haematological and immunological characteristics of weanling piglets. J. Anim. Phys. Nutr. (Berl.) 98:680-685

Ferreira, L. S., and C. M. M. Bittar. 2011. Performance and plasma metabolites of dairy calves fed starter containing sodium butyrate, calcium propionate, or sodium monensin. Animal 5:239-245.

Górka, P., Z. M. Kowalski, P. Pietrzak, A. Kotunia, W. Jagusiak, J. J. Holst, P. Guilloteau, and R. Zabielski. 2011a. Effect of method of delivery of sodium butyrate on rumen development in newborn calves. J. Dairy Sci. 94:5578-5588.

Górka, P., Z. M. Kowlaski, P. Pietrzak, A. Kotunia, W. Jagusiak, and R. Zabielski. 2011b. Is rumen development in newborn calves affected by different liquid feeds and small intestine development? J. Dairy Sci. 94:3002-3013.

Górka, P., P. Pietrzak, A. Kotunia, R. Zabielski, and Z. M. Kowalski. 2014. Effect of method of delivery of sodium butyrate on maturation of the small intestine in newborn calves. J. Dairy Sci. 97:1026-1035.

Górka, P., M. Kowalski, R. Zabielski, and P. Guilloteau. 2018. Invited review: Use of butyrate to promote gastrointestinal tract development in calves. J. Dairy Sci. 101:4785-4800.

Guilloteau, P., G. Savary, Y. Jaguelin-Peyrault, V. Romé, L. Le Normand, and R. Zabielski. 2010. Dietary sodium butyrate supplementation increases digestibility and pancreatic secretion in young milk-fed calves. J. Dairy Sci. 93:5842-5850.

Guilloteau, P., R. Zabielski, and J. C. David. 2009. Sodium butyrate as a growth promoter in milk replacer formula for young calves. J. Dairy Sci. 92:1038-1049.
Heinrichs, A. J. 1993. Raising dairy replacements to meet the needs of the 21st century. J. Dairy Sci. 76:3179-3187.

Herrick, K. J., A. R. Hippen, K. F. Kalscheur, D. J. Schingoethe, S. D. Ranathunga, J. L. Anderson, S. C. Moreland, and J. E. van Eys. 2018. Infusion of butyrate affects plasma glucose, butyrate, and $\beta$-hydroxybutyrate but not plasma insulin in lactating dairy cows. J. Dairy Sci. 101:3524-3536. https://doi.org/10.3168/jds .2017-13842.

Hu, Z., and Y. Guo. 2007. Effects of dietary sodium butyrate supplementation on the intestinal morphological structure, absorptive function and gut flora in chickens. Anim. Feed Sci. Technol 132:240-249. https://doi.org/10.1016/j.anifeedsci.2006.03.017.

Huhtanen, P., H. Miettinen, and M. Ylinen. 1993. Effect of increasing ruminal butyrate on milk yield and blood constituents in dairy cows fed a grass silage-based diet. J. Dairy Sci. 76:1114-1124.

Kotunia, A., J. Wolinski, D. Laubitz, M. Jurkowska, V. Romé, P. Guilloteau, and R. Zabielski. 2004. Effect of sodium butyrate on the small intestine development in neonatal piglets fed by artificial sow. J. Physiol. Pharmacol. 55(Suppl. 2):59-68.

Krehbiel, C. R. D. L. Harmon, and J. E. Schnieder. 1992. Effect of increasing ruminal butyrate on portal and hepatic nutrient flux in steers. J. Anim. Sci. 70:904-914.

Leeson, S., H. Namkung, M. Antongiovanni, and E. H. Lee. 2005. Effect of butyric acid on the performance and carcass yield of broiler chickens. Poult. Sci. 84:1418-1422.

NRC. 2001. Nutrient Requirements of Dairy Cattle. 7th rev. ed. National Academy Press, Washington, DC.

Piva, A., M. Morlacchini, G. Casadei, P. P. Gatta, G. Biagi, and A. Prandini. 2002. Sodium butyrate improves growth performance of weaned piglets during the first period after weaning. Ital. J. Anim. Sci. 1:35-41.

Sander, E. G., R. G. Warner, H. N. Harrison, and J. K. Loosli. 1959. The stimulatory effect of sodium butyrate and sodium propionate on the development of rumen mucosa in the young calf. J. Dairy Sci. 42:1600-1605.

Tamate, H., A. D. McGilliard, N. L. Jacobson, and R. Getty. 1962 Effect of various dietaries on the anatomical development of the stomach in the calf. J. Dairy Sci. 45:408-420.

Van Keulen, J., and B. A. Young. 1977. Evaluation of acid-insoluble ash as a natural marker in ruminant digestibility studies. J. Anim. Sci. 44:282-287.

Van Soest, P. J., J. B. Robertson, and B. A. Lewis. 1991. Methods for dietary fiber, neutral detergent fiber, and nonstarch polysaccharides in relation to animal nutrition. J. Dairy Sci. 74:3583-3597. 